\title{
Using Site-specific Approaches to Advance Potato Management in Irrigated Systems
}

\author{
Joan R. D avenport ${ }^{1}$ and M ary J. H attendorf ${ }^{2}$
}

Additional INDEX wORDs. Solanum tuberosum, center pivot, variable rate applications, ET, evapotranspiration, crop rotations

Summary. Potatoes (Solanum tuberosum L.) are grown extensively throughout the Pacific northwestern $U$ nited States as a high value crop in irrigated rotations with other row crops such as wheat (Triticum aestivum L.) and both field and sweet corn (Zea mays L.). C enter pivots are the predominant irrigation systems. Soil texture ranges from coarse sands to finer textured silt loams and silts and can vary within one field, particularly in fields with hilly topography. Site specific management is being evaluated as an approach to help to optimize inputs (water, seed, agricultural chemicals) to maintain or enhance yield and reduce potential negative environmental impacts from these farming systems. C urrently, variable rate fertilizer application technology and harvest yield monitoring equipment are commercially available for potato. V ariable rate seeding and variable rate irrigation water application technologies are developed but not fully commercialized and variable rate pesticide application equipment is in development. At the I rrigated Agricultural Research and Extension Center in Prosser, Wash., we have a team of research scientists, interested individuals from local industry, and other key organizations (e.g. local conservation districts) who are working together to evaluate different site specific technologies, improve the ability to use available tools, and to improve decisionmaking ability by conducting research both on farm and in research plots.

T

he concept of precision farming, or site-specific crop management (SSCM) is to manage inputs for agricultural production systems to meet both spatial and temporal variability in production. Early work on this concept focused on agronomic crops grown on large acreage in the midwestern $U$ nited States. $\mathrm{H}$ owever, as tools and technologies have become more advanced, there has been a shift to looking at SSCM approaches for horticultural crops.

In the irrigated production areas of the Pacific northwestern U .S., potato (Solanum tuberosum) is grown on large fields [ 55 ha ( 120 acres) ], predominantly under center pivot irrigation. These large fields have a high degree of spatial variability in soil factors and crop yield ( $\mathrm{H}$ an et al., 1996) and are known to have temporal variability in water and nutrient demand (Evans et al., 1996).

${ }^{1}$ Assistant professor, soil scientist, D epartment of C rop and Soil Science, Washington State U niversity I rrigated Agriculture Research and Extension Center, Prosser, WA 99350.

2D irector, Washington Public Agriculture Weather N etwork: Biological Systems Engineering, Washington State U niversity I rrigated Agriculture Research and Extension Center, Prosser, WA 99350. 


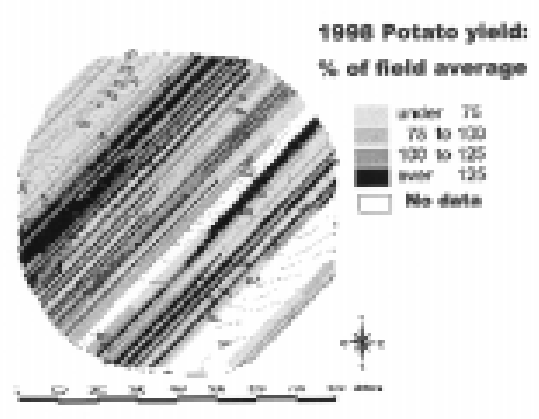

b

a

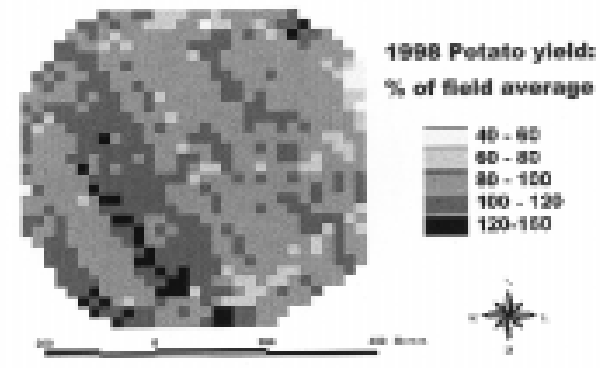

Fig. 1. Yield map of potato in 1996 (A) and 1998 (B) showing progression in ability to monitor the entire field without data gaps; $1.0 \mathrm{~m}=3.3 \mathrm{ft}$.

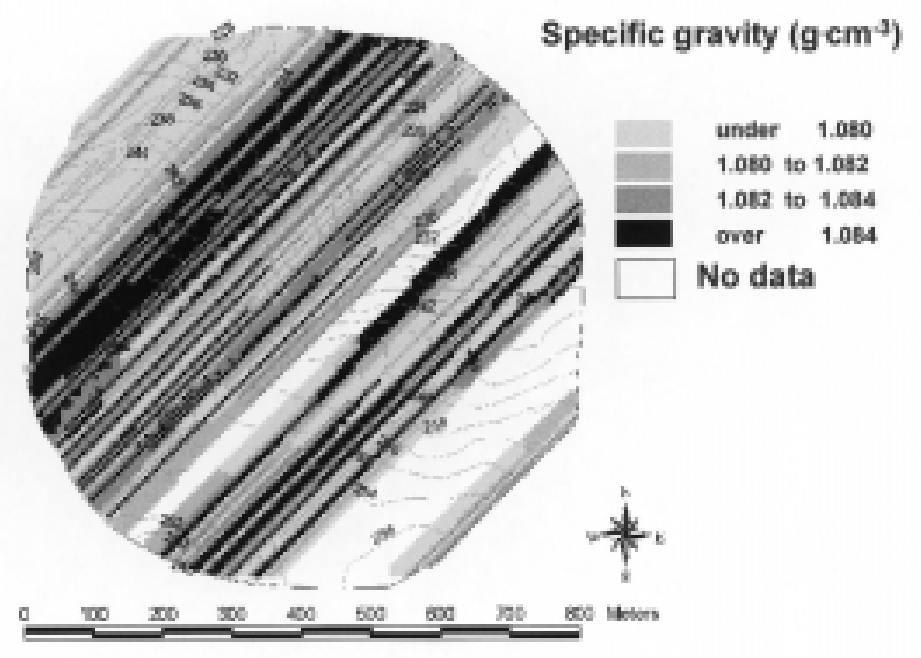

initiated at the I rrigated Agricultural Research and Extension Center (IAREC) in Prosser, Wash. The initial team was made up of both federal (U SDA-ARS) and state (Washington State U niversity) scientists at IAREC. Within oneyear of theteam'sinception, partners from a number of industries were asked to join. The team now has involvement from a number of partners ranging from irrigation equipment companiesto a large multinational electronics firm, county conservation districts, and local farmers. Efforts have been underway to develop an understanding of the potato system and to begin implementing SSCM practices. This paper discussesaccomplishmentsand what the future may hold for potato production should these technologies be fully adapted and adopted.

\section{Advances in precision potato management}

YIELD AND QUALITY MONITORING. U nproaches for improved production economicsand reduced potential negative environmental impacts.

To develop SSCM approachesfor irrigated potato rotation systems in the Pacific northwestern United States, a team effortwas derstanding variability in potato yield and quality is important for developing an understanding of the factors that can be modified to reduce variability. Thus, the development of yield monitoring equipment was amongst the first efforts towards developing SSCM approaches in potato. This work was conducted collaboratively with an industry partner. Yield monitoring equipment for potato involves using load cells on the belt of a commercial potato harvest equipment in combination with a global positioning system (GPS) monitoring device to collect potato weight and location during harvest (Schneider et al., 1996). Early efforts during the equipment development phase resulted in yield maps
Fig. 2. Map of potato specific gravity (sg) from 1996 where sg measurements were taken as a bulk measurement from a truckload of potatoes and integrated across the harvested $\operatorname{row}(\mathrm{s}) ; \mathbf{1 . 0} \mathrm{m}=\mathbf{3 . 3} \mathrm{ft}$.

Additionally, recently published water quality survey information indicates that there are problems with nitrate contamination in wells in the area associated with potato production (Williamson et al., 1998). Thus, the potato production system offersan ideal situation for developing SSCM ap-

Fig. 3. Potato specific gravity taken as point data samples and integrated

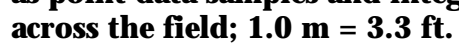
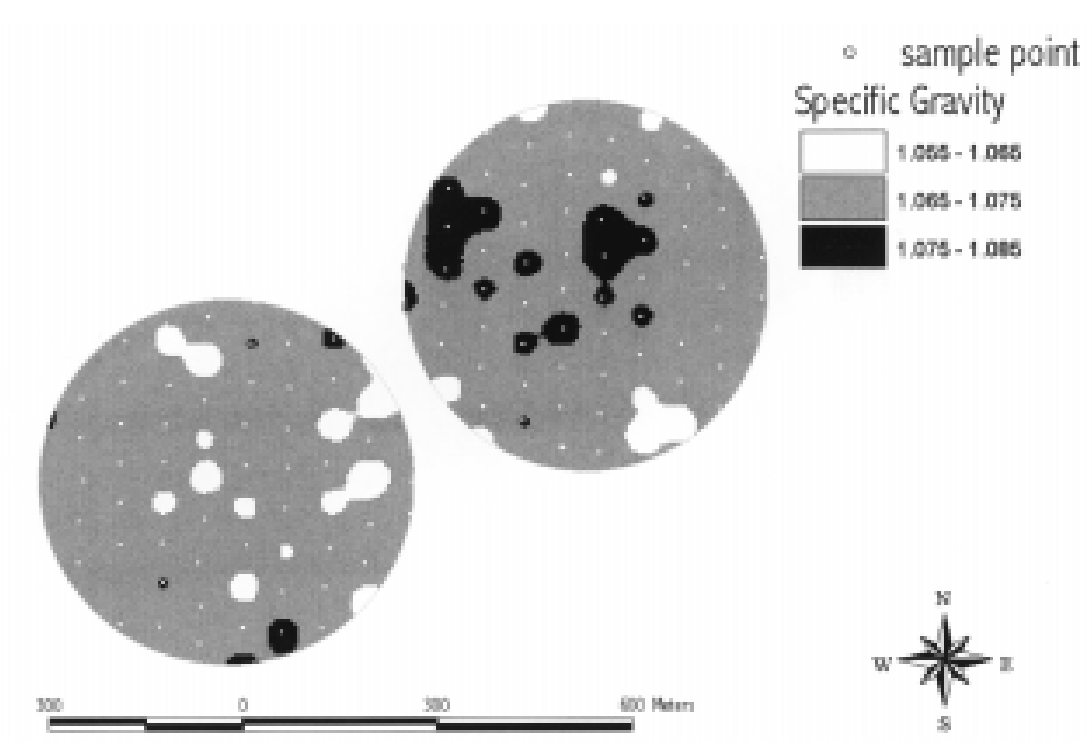

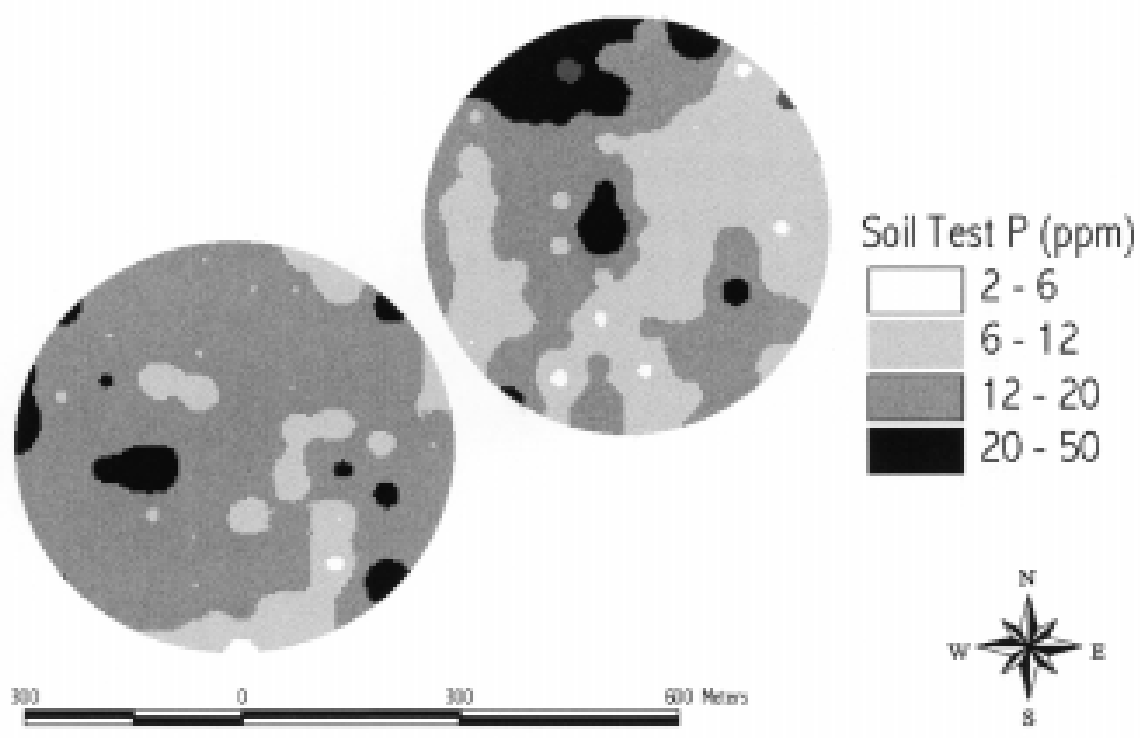

Fig. 4. Spatial variability in soil test $P$ in two adjacent potato fields; $1.0 \mathrm{~m}$ $=3.3 \mathrm{ft}$.

with numerous data gaps. $\mathrm{H}$ owever, by 1998 our team successfully harvested whole fields with few to no data gaps (Fig. 1).

Monitoring potato quality has been more difficult. Although yield is an important component of potato production and marketing, processpotato pricing is influenced by both size distribution and specific gravity. Early approaches for monitoring variability in potato quality involved collecting subsamples of potato tubersfrom individual trucks, evaluating them for quality, and georeferencing the data to the harvested strip (Fig. 2). To develop more specific data, sampling is now being conducted by collecting samples from specific geo referenced points in a monitored field (Schneider et al., 1997) by harvesting a $10-\mathrm{ft}(3.07-\mathrm{m})$ row length before commercial harvest, and evaluating these samples for quality (Fig. 3). Although this approach is well suited to a research situation, it is not feasible for commercial operations. Efforts are currently underway to modify the current yield monitoring devicethat would allow real-time measurement of potato quality during harvest (S. Rawlins, personal communication).

These advances have resulted in equipment for real-time potato yield monitoring that is commercially available. H owever, its operation is still sophisticated enough that it is not widely commercially adapted. Continued refinements of thetechnology plus the addition of quality monitoring show promise for yield monitoring to become more than a research tool.

VARIABLE RATE FERTILIZER APPLICATION. Perhaps the greatest technological advancesin SSCM and variable rate technology (VRT) are those which have been made for granular fertilizer application. Commercial equipment is availableto makeVRT applicationsfor row crops as well as orchard and vineyard crops. H owever, the ability of the equipment to apply fertilizers at variable rates may exceed our ability to predict variability in fertilizer requirement as finely as it can be applied.

In potato, VRT fertilizer application is predominantly for $P, K$, and $S$, although some preplant $N$ is variably applied. Advanced systems that provide VRT water application can also provide VRT fertigation (King et al., 1996) for in-season N application.

Perhaps one of the biggest ques- tions in VRT fertilizer application is soil sampling to determinespatial variability. I isgenerally agreed that smaller sampling densities providebetter guidance in predicting variability in fertilizer needs (Wollenhaupt et al., 1994). $\mathrm{H}$ owever, there needs to be a balance between a sampling density that provides a good predictor and high sampling densities that exceed the economic gains from spatially variable fertilizer application. Research with potato has suggested that a 1-acre (61 $\times$ 61-m) grid size for soil sampling is appropriate (M . H ammond, personal communication). An alternative strategy for multiple soil sampling in a single field is to use a directed or smart sampling approach (Pocknee et al., 1996). I n thesmart sampling approach, soil is sampled at densities that are both finer and coarser than a 1 acre grid suggests. Sampling densities are established using field history (e.g., yield, management practices) to direct the sample density for increased economic gain from each sample (i.e., finer density in areas of greater variability, coarser in more uniform areas). Currently effortsareunderway in Washington to compare efficacy of VRT fertilizer decisions based on conventional (single soil test), grid sampling, and smart sampling in potato.

Another aspect of soil sampling that affects decision making for VRT fertilizer application is the actual soil

Fig. 5. Spatial variability in soil pH in two adjacent potato fields. Sample points represent points where soil samples were collected on a 1 acre grid; $1.0 \mathrm{~m}=3.3 \mathrm{ft}$.

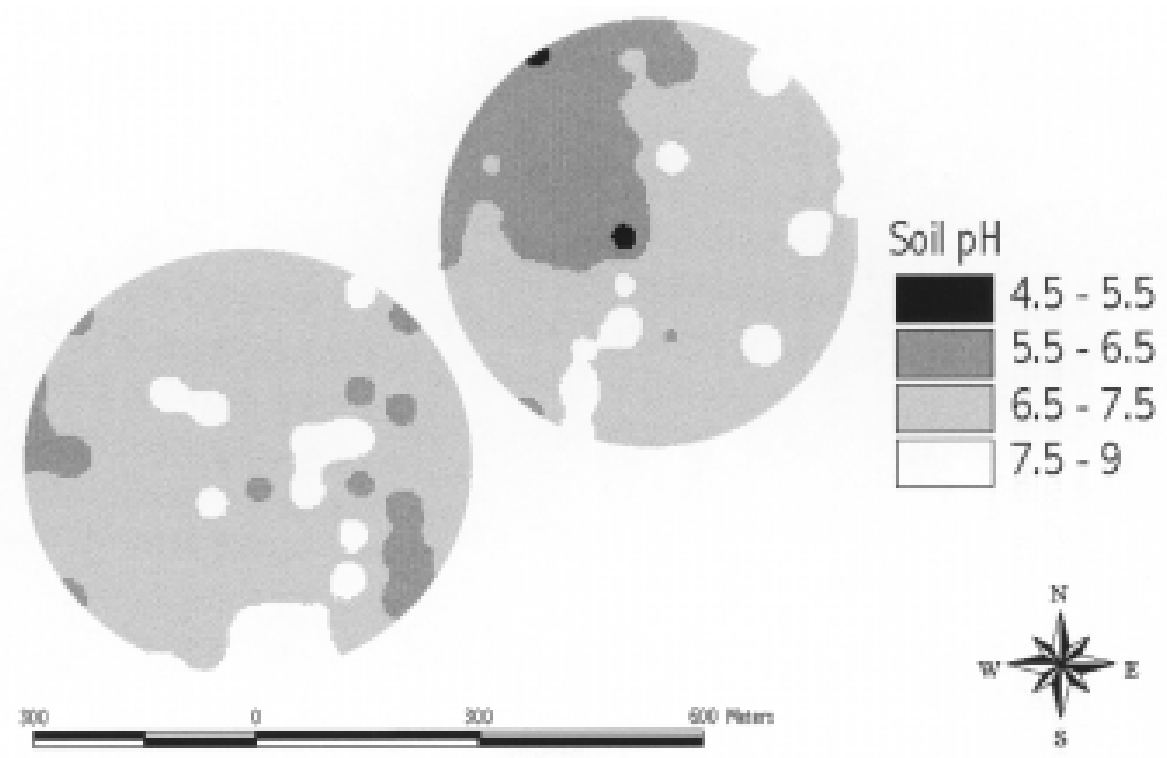




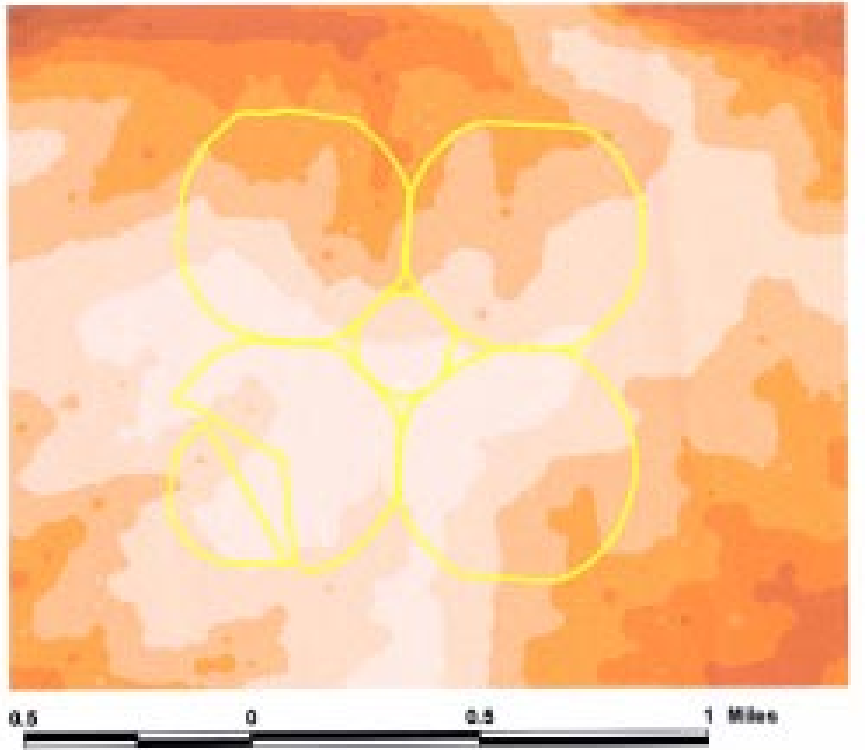

Fig. 6. Field elevation across a landscape containing five fields of irrigated row crops in central Washington; $1.0 \mathrm{~km}=0.62$ miles.

test procedure and the interpretation of results. M ethod development for soil testing wasconducted on soils that camefrom very small, controlled plots, historically at land grant universities and research stations. Thegoal of these programswas to develop a singlenumber that most closely related to the amount of a given nutrient (generally $P$ and $K$ ) that a plant could effectively extract from the soil during a single growing season. It has long been understood that chemical extraction methods developed for soil test are predictions, not absolutes. There are several aspects of nutrient management for precision farming that challenge the applicability of using single element soil test values as the basis of predicting variable rate fertilizer needs across the large fields ( $\mathrm{H}$ ergert et al., 1997) used for potato farming. $O$ ne is that large fields have a great deal more variability than the small plots which were used to develop soil test values. A second is that the availability of sophisticated information handling systems (computers with spreadsheets and/ or geographic information system (GIS) programs) now makes it relatively easy to use more than a single value to predict fertilizer need. Figures 4 and 5 show variability of both soil test $P$ and soil pH in two potato fields. T wo years of research on this farm indicated that there was a stronger correlation between $\mathrm{P}$ fertilizer response and soil pH

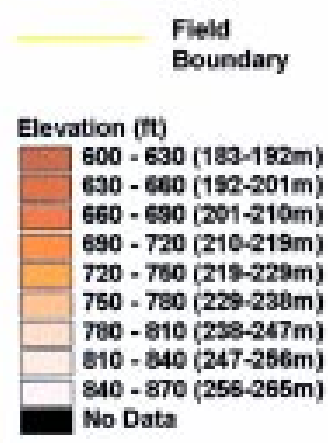

than with soil test $P$ ( $D$ avenport et al., 1999). This suggests that multifactorial models for variably applying fertilizers to potato will result in greater nutrient use efficiency and improved economic returns.

Although much of the work on VRT fertilizers has focused on preplant granular fertilizer applications, the ability to apply nutrients, especially nitrogen, variably through the irrigation system during the season increasestheneed for largescalenondestructive monitoring of potato nutrient demand. There are several approachesthat can beused. $\mathrm{H}$ istorically in-season nitrogen need in potato is determined through monitoring petiole soluble nitrogen content. $\mathrm{H}$ and held ion-selective electrodes offer an opportunity to conduct nitrate analysis on petiole samples on site without waiting for test lab results (E rrebhi et al., 1998). H owever, such devices still require destructive sampling and are time-consuming. I on exchange resin technology has advanced to the point where devices can be inserted into the field, removed at variousintervals(e.g., 24 h, 2 weeks), extracted, and used to determine nutrient flux through the rootzone (Q ian and Schoenau, 1995). Although nondestructive, this technique does not provide the instantaneous, spatially integrated information that is desired for monitoring large fields for crop nutrient demand (Frazier et al., 1997).

Currentlyweareworking on evaluating canopy reflectance and photosynthetic kinetic measurements as possible technologies for nondestructive nutrient and water stress response in potato. This work is very preliminary, but the data suggest that the different stresses have distinct and separate signals that can be identified by both technologies. Prototype equipment for monitoring is being field tested this (1999) crop year. Successin developing thistype of equipment and integrating the information transfer into a GI S program would provide real-time feedback for applying inseason variable rate nitrogen to potato through a center pivot irrigation system.

VRT WATER APPLICATION AND PLANT DEMAND. As researchers have collected data on spatial variability in potato yield in the Pacific northwestern U.S.,

\section{Fig. 7. Variation in evapotransipration (ET) demand across whole fields for a single day of the growing season.}

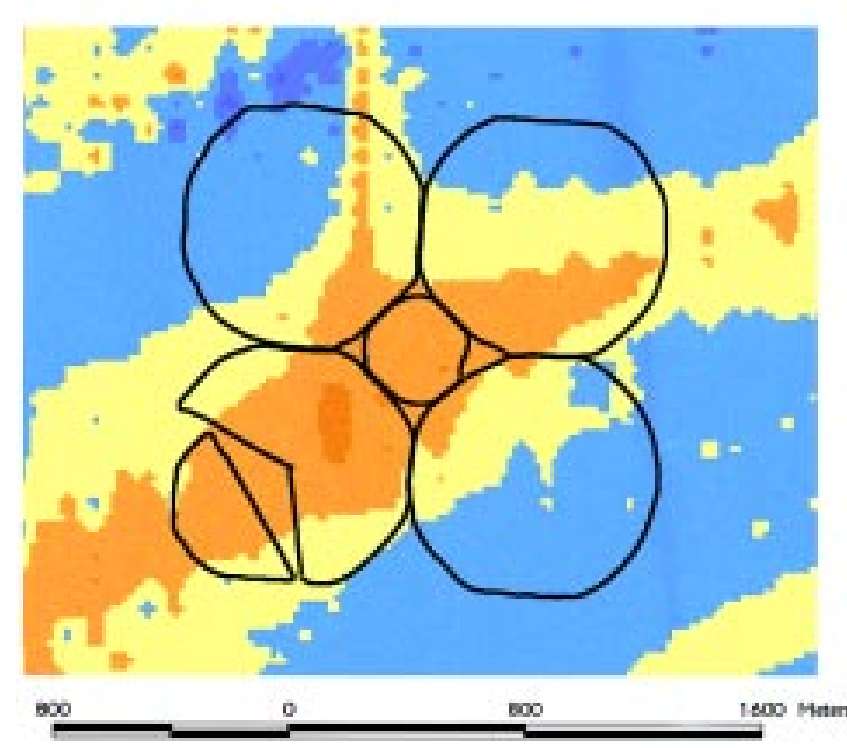

Fieid Boundary 
an interesting finding has emerged. Consistently, the single factor correlated with yield is elevation. $D$ ata from Washington State has shown yield to be positively correlated with elevation, which researchers concluded was actuallyacorrelation with soil moisture $(\mathrm{H}$ an et al., 1996). Research in Idaho has shown a negative correlation between yield and el evation ( $O$ jalaand $C$ hiappini, 1998) which likely supports the Washington findings and could indicate a difference in irrigation management strategies in the two growing areas.

In potato, crop water demand varies both spatially and temporally ( $H$ attendorf, 1991). An irrigation system that provides water variably across a management area could increasecrop yield and quality, decrease the area in a field susceptible to the fungal rot organism late blight (Phytopthora infestans L.), and reduce potential nutrient leaching. Two different approaches have been used to develop prototype VRT water application systems through center pivot for potato production. O ne technology uses individual solenoid controllers on each nozzle to control the duration of the water application, allowing the water to be pulsed on or off for a specific length of time (Evans et al., 1996). The second technology uses a double nozzle approach. At the end of each water line hanging from the pivot (the drop line), the line is split and two nozzles are attached. The nozzles are differentially sized to allow a configuration where each drop emitter can provide $0,33 \% 67 \%$ or $100 \%$ of the drop line capacity (King et al., 1995). Both systems are controlled to meet spatially variable demand through GIS programing for variability in soil texture and land scape position. Currently a large corporate farm is adapting and adopting the first of these two technologies for irrigated potato. A commercial firm is investigating the feasibility of the second technology.

I rrigation scheduling using VRT combines knowledge of spatially variable soil water-holding capacity, spatial and temporal variability of applied water, system delivery specifications, and weather-driven crop evapotranspiration (ET) calculations. In nonVRT applications, a single value of crop evapotranspiration istypicallyused for entire fields or areas for use in irrigation scheduling software. Breaking a field into smaller management zones with separate estimates of ET for each zone requires more data from infield sensors, or reliable methods to model weather data at grid points in the field. T wo methods of modeling weather data at grid locations could be used, depending on the variable. O ne method is to estimate scalar variables (e.g., temperature, relative humidity, and solar radiation) by geostatistics, providing that enough data are available for the procedure. Estimation using process-driven modelsisanother method, which is better suited for modeling wind speed and direction. Several models for high-resolution, small area wind modeling are available that have accessible data requirements. $O$ ften only one data site is required for model initiation.

As part of our SSCM efforts in potato, the WADOCT model (wind and diffusion over complex terrain) model (Kunkle and I zumi, 1990) was chosen to illustrate the concept of field-scale, spatially variable ET calculations. Data inputs for this modeling were taken from a weather station at a commercial potato farm in Eltopia, Wash. The datainputsinto WAD OCT included air temperature at $1.6 \mathrm{~m}(5.2$ $\mathrm{ft})$ and $10 \mathrm{~m}(32.8 \mathrm{ft})$, wind speed and direction at $10 \mathrm{~m}$, digital elevation model (DEM) data thinned to $90 \mathrm{~m}$ ( $295.3 \mathrm{ft}$ ) (Fig. 6), $13 \mathrm{~cm}$ (5.1 inches) vegetative roughness, corner grid coordinates, coordinates of the weather station, and the grid interval. Additional available data included relative humidity and solar radiation at $1.5 \mathrm{~m}$ $(4.9 \mathrm{ft})$, and wind speed at $2 \mathrm{~m}(6.6 \mathrm{ft})$. Evapotranspiration was calculated at each grid point (Fig. 6) at $15 \mathrm{~min}$ intervals by $L E=(R N-G)-\rho C_{p}(T c-$ $\mathrm{Ta}) / r_{a^{\prime}}$ where $L E$ is latent energy or evapotranspiration in $\mathrm{W} \cdot \mathrm{m}^{-2}$ (langleys/ min), $\mathrm{RN}$ is net radiation in $\mathrm{W} \cdot \mathrm{m}^{-2}$ (langleys/ $\min$ ), $G$ is soil heat flux in $\mathrm{W} \cdot \mathrm{m}^{-2}, \rho \mathrm{C}$ is heat capacity at constant pressure, ${ }^{p} c$ is canopy temperature $\left({ }^{\circ} \mathrm{C}\right.$ or $\left.{ }^{\circ} \mathrm{F}\right)$, and $\mathrm{Ta}$ is air temperature $\left({ }^{\circ} \mathrm{C}\right.$ or $\left.{ }^{\circ} \mathrm{F}\right)$ at $1.5 \mathrm{~m}$. Soil heat flux was estimated as $5 \%$ of $\mathrm{RN}$. N et radiation was estimated following $D$ ong et al. (1992). All variables except wind speed and direction were the same at each grid point. Calculated ET at a given time varied spatially with gridded output from the wind model.

A framework for ET calculations based on remotely sensed T $\mathrm{c}$ was developed using the arbitrarily constructed relationship T c - Ta $=1.0-1.8 \times$ vapor pressure deficit in $\mathrm{kPa}$ (bars). ET values were then averaged over the entire grid and percent changefrom the mean field ET was calculated (Fig. 7).

Results showed that wind speeds varied from 0.8 to $2.6 \mathrm{~m} \cdot \mathrm{s}^{-1}$ (1.8 to 5.8 miles/ h) at $1200 \mathrm{H} \mathrm{R}$ on day 228 . Wind direction across the $2 \mathrm{~km}^{2}$ (1.2 miles $)$ varied from south southeast to west northwest, with highest wind speeds associated with southerly winds and the ridge top. Lowest wind speeds were associated with lower elevation (draws in the study area). M ean wind direction was from the south. Flows counter to that direction in the northwest portion of the study area were associated with deep draws. Wind run (total distance traveled from 0800 to $1900 \mathrm{HR}$, day 228) was greatest across the higher elevations of the study area. Based on wind travel, expected ET would be higher on hilltops and ridge tops.

$C$ alculated total daily $\mathrm{ET}$ ranged from 7 to $9 \mathrm{~mm}$ (0.28 to 0.35 inches) on day 228 , which are reasonable values for the region and season. Percent change in calculated ET from the field mean ranged from $-15 \%$ to $-10 \%$ in the deepest draw to $+10 \%$ to $15 \%$ on the ridge top (Fig. 7).

Conclusions drawn from this study are

- the model can help identify areas with high or low wind speed with the implications that

- areaswith decreased wind run (ventilation) could be more at risk for diseaseincidence. A windflow model could help identify such areas.

- areas of increased ventilation could more readily transport disease spores.

- areasof deviant wind direction could be identified and information used in feedback for irrigation nozzle control.

- potential new areas of disease outbreak could be identified by knowing wind vectors in infected areas

- much of theET change occurred in the $-5 \%$ to $5 \%$ range, but in the central ridge top zone, ET ranged from $5 \%$ to $15 \%$ of the study mean.

- Wind speed variation contributed to changes in ET of up to $10 \%$ to $15 \%$ and should be considered in complex terrain.

O ngoing work includes the validation of WAD O CT and other appropriate models for local conditions.

VRT SEeding. T echnology for VRT seeding was initially developed for ag- 
ronomic crops like corn and wheat, using the technology to vary planting rate or variety (Anderson and $\mathrm{H}$ umburg, 1997). Adapting the technology to the large seed piece used for potato planting has required changes in the planter design but not in the other equipment for operation. Research in I daho hasindicated that both yield and quality gains can be made through varying potato planting density with spatial variability in soil textureand compaction, topography, and water deposition patterns ( $H$ ess et al., 1998). I n addition to yield and quality gains, variable seed piece spacing in potato could be used with newly developed pest resistant varieties where the resistant varieties could be planted in high risk areafor pathogen or insect populations. This selective planting of genetically altered seed offers the possibility of improving economics and decreasing resistance development.

VRT PEST CONTRol. Probably one of the more difficult aspects in VRT technology is developing systems for variable rate application of pest control chemicals. D ifferential seeding with resistant varieties is one possible approach but, currently, commercially available potatoes with pest resistance are limited, although more are certainly in development (Corsini et al., 1999). Weed activated spot sprayers are commercially available but must be set up with sensors that allow spectral differentiation of leaf reflectance between the crop plant and weed species (Anderson and Humburg, 1997; Sudduth et al., 1997).

Center pivot irrigated potato systems offer a unique opportunity to attach a separate boom to the pivot to apply variableratesprayswhereneeded. As with the weed activated spot sprayers, technology to determine where pest problems are needed to effectively develop these sprayers (Sudduth et al, 1997). Advances in pattern recognition software, high resolution satellite or aerial imagery, and/ or other nondestructive means of monitoring pest pressure are needed before VRT pest control in potato can be implemented.

\section{Summary and conclusions}

$U$ sing SSCM for management in potato has promise to help advance potato production from both economic and environmental aspects. The tools currently commercially availableto potato growers are yield monitoring and
VRT fertilizer application equipment. Better understanding of the information needed to makefertilizer usemanagement decisionsisneeded plusmodification of the yield monitoring equipment to include information on quality will enhance the use of these devices. 0 ther equipment in various stages of commercial development has the potential to greatly enhance both economic and environmental benefits of SSCM in potato-particularly in arid irrigated systems. Advancements in nondestructivecrop monitoring will also greatly enhance the commercial adaptation of SSCM in potato. In the future it is highly likely that potato management will be largely through very integrated, auto mated, computer driven packages that can be adjusted across large field expanses to optimize inputs and returns.

\section{Literature cited}

Anderson, N.W. and D.S. H umburg. 1997. Application equipment for site-specific management, $p$. 245-281. In: F.J . Pierce and E.J. Sadler (eds.). The state of site specific management for agriculture. ASA-CSSA-SSSA Press, M adison, Wis.

Corsini, D., J. Pavek, C. Brown, D. Inglis, M M artin, M. Powelson, A. D orrance, and H . L ozoyaSaldaña. 1999. Late blight resistant potato germplasm release AWN 86514-2. Amer. J. Potato Res. $76(1): 45-50$.

D avenport, J.R., M .J . H attendorf, and R.E. Evans. 1999. L arge scale phosphorus field trials for developing VRT fertilizer needsmodels. Proc. W. N utrient M gt. Conf. 3:16-25.

Dong, A., S.R. Grattan, J.J. Carroll, and C.R.K. Prashan. 1992. Estimation of daytimenet radiation over well-watered grass. J. Irr. Drainage Eng. 118:466-479.

Errebhi, M., C.J. Rosen, and D.J. Birong. 1998. Calibration of petiole sap nitrate test for irrigated 'Russet Burbank' Potato. Commun. Soil Sci. Plant Anal. 29:23-35.

Evans, R.G, S. H an, S.M. Schneider, and M.W. Kroeger. 1996. Precision center pivot for efficient use of water and nitrogen, p. 75-84. In: P.C. Robert (ed.). Proc. 3rd Intl. Conf. Precision Agr. ASA-CSSA-SSSA Press, M adison, Wis.

Frazier, B.E., C.S. Walters, and E.M. Perry. 1997. Role of remote sensing in site-specific management, p. 149-160 In: F.J. Pierce and E.J. Sadler (eds.). The state of site specific management for agriculture. ASA-C SSA-SSSA Press, $M$ adison, Wis.

$\mathrm{H}$ an, S., R.G. Evans, S.M. Schneider, and S.L. Rawlins. 1996. Spatial variability of soil properties on two center-pivot irrigated fields, p. 97-106. In: P.C. Robert (ed.). Proc. 3rd Intl. Conf. Proc. Agr. ASA-CSSA-SSSA Press, M adison, Wis.

$\mathrm{H}$ attendorf, M.J. 1991. Climate, irrigation, and nitrogen rate effects on 1990 potato yields. Proc. 1991 W ash. State Potato C onf. and T rade Show. p. 5-11.
H ergert, G.W., W.L. Pan, D.R. H uggins, J.H . Grove, and T.R. Peck. 1997. Adequacy of current fertilizer recommendations for site-specific management, p. 283-300. In: F.J. Pierce and E.J. Sadler (eds.). The state of site specific management for agriculture. ASA-CSSA-SSSA Press, M adison, Wis.

H ess, J.R., J.M. Svoboda, R.L. H oskinson, D.W H empstead, and W.B. Jones. 1998. Spatial potato seed piece placement monitoring system, p. 653660. In P.C. Robert (ed.). Proc. 4th Intl. Conf. Precision Agr. ASA-CSSA-SSSA Press, Madison, Wis.

King, B.A., R.A. Brady, I.R. McCann, and J.C. Stark. 1995. V ariableratewater application through sprinkler irrigation, p. 485-493. In: F.J. Pierce and E.J. Sadler (eds.). The state of site specific management for agriculture. ASA-C SSA-SSSA Press, M adison, Wis.

King, B.A, J.C. Stark, I.R. M cCann, and D.T. Westemann. 1996. Spatially varied nitrogen application through a center pivot irrigation system, $p$. 85-94. In: P.C. Robert (ed.). Proc. 3rd Intl. Conf. Precision Agr. ASA-CSSA-SSSA Press, Madison, Wis.

Kunkel, B.A., and Y. I zumi. 1990. WAD O CT - An atmospheric dispersion model for complex terrain. GL-TR-90-0124 Environmental Res. Paper 1062. Atmos. Sci. Div. Project 6670, Geophysics Lab., $\mathrm{H}$ anscom AFB, M ass.

O jala, J. and R. Chiappini. 1998. Relationship between yield, elevation, slope and aspect in precision fertilized potato field. Potato Assn. Amer. Abstracts 18

Pocknee, S., B.C. Boydell, H .M. Green, D.J. Waters and C.K. Kvien. 1996. D irected soil sampling, p. 159-168. In: F.J. Pierce and E.J. Sadler (eds.). The state of site specific management for agriculture. ASA-CSSA-SSSA Press, M adison, Wis.

Q ian, P and J.J. Schoenau. 1995. Assessing nitrogen mineralization from soil organic matter using anion exchange membranes. Fert. Res. 40:143148.

Schneider, S.M., S. H an, R. H. Campbell, R.G. Evans, and S.L. Rawlins. 1996. Precision agriculture for potatoes in the Pacific N orthwest, p. 443452. In: P.C. Robert (ed.). Proc. 3rd Intl. Conf. Precision Agr. ASA-CSSA-SSSA Press, Madison, Wis.

Schneider, S.M , R.A. Boydston, S. H an, and R.G. Evans. 1997. M apping of potato yield and quality, p. 253-261. In J.V. Stafford (ed.). Precision agriculture '97. vol. I: Spatial variability in soil and crop. Bios Scientific Publ., London.

Sudduth, K.A., J.W. H ummel, and S.J. Birrell. 1997. Sensors for site-specific management, $p$. 183-208 In: F.J. Pierce and E.J. Sadler (eds.). The state of site specific management for agriculture. ASA-CSSA-SSSA Press, M adison, Wis.

Williamson, A.K., M.D. M unn, S.J. Ryker, R.J. Wagner, J.C. Ebbert, and A.M . Vanderpool. 1997. Water quality in the central Columbia Plateau, Washington and Idaho, 1992-95. USGS Circ. 1144.

Wollenhaupt, N.C., R.P. Wolkowski, and M . Clayton. 1994. M apping soil test phosphorus and potassium for variable rate fertilizer application. J. Prod. Agr. 7:441-448. 